\title{
Metadiscourse and College English Interpretation Teaching
}

\author{
Lina Wang* \\ Shanghai Medical Instrumentation College \\ USST \\ Shanghai, China \\ belovedcici@yahoo.com \\ *Corresponding author
}

\author{
Ju Fang \\ School of English Studies \\ Dalian University of Foreign Languages \\ Dalian, China.
}

\begin{abstract}
Metadiscourse can be used to organize discourse, express writers/speakers' viewpoints towards discourse and attitudes towards readers/listeners, communicate and negotiate with readers/listeners. This study applied the metadiscourse theories into college English interpretation teaching. Through the statistic analysis of teaching experiment among 56 English majors and the interview conducted later, the study shows that metadiscourse training helps with the improvement of students' interpretation achievement.
\end{abstract}

Keywords-metadiscourse; college English; interpretation teaching

\section{INTRODUCTION}

According to Mei Deming [1], simply speaking, interpretation is a kind of vocal communicative activity by listening to and decoding the information expressed by the source language speakers and then interpreting it into the target language. With the improvement of the overall English level of Chinese college students, and the international activities held in China such as Olympic Games 2008 in Beijing, World Expo 2010 in Shanghai and APEC 2014 in Beijing, there is a sharp increase in the demand for interpreters. In addition, English Syllabus for College English Programs published in 2000 set the training objectives for English majors as "College English programs aim at training compound English talents engaged in translation, teaching, administration, research and other work in foreign affairs, education, economy and trade, culture, science and technology, military and other departments with solid foundation in English language and culture knowledge”. And the interpretation course was positioned as English professional skill course in the syllabus. At present, most English programs in Chinese universities and colleges have interpretation course in which the basic theories of interpretation, interpretation methods and skills are generally attached great importance to. The interpretation course contents cover listening training, memory training, numbers interpretation, interpretation note taking and so on. Researches on college English interpretation mainly focus on theories of interpretation, interpretation teaching, interpretation needs analysis, interpretation test etc. Empirical studies which apply the relative metadiscourse theories to interpretation teaching are not found yet.

\section{THEORETICAL RESEARCHES ON METADISCOURSE}

Jiang Hui and Cheng Xiaoguang [2] pointed that the term "metadiscourse" was first put forward by Z. Harris in 1959. This term was used by him to refer to the information in a less important role in discourse. Its manifestations are mainly words, phrases, sentences, punctuations, charts and even paragraphs. Since then, Williams (1981), Vande Kopple (1985), Crismore (1989), Hyland (2000, 2002, 2005) et al. further developed this term. Crismore [3] pointed out that any forms of language communication include two aspects. One is the primary discourse or text level. The other is the metadiscourse level. The primary discourse is the information related with discourse topics, including propositional contents and referential meanings. Metadiscourse is mainly composed by propositional attitudes, textual meanings and interpersonal meanings. Although different researchers have defined metadiscourse from different angles, most researchers agreed on its realization of textual and interpersonal functions. That is to say, metadiscourse can be used to organize the discourse, express the writer/speaker's discourse views and their attitudes to readers/listeners and make interpersonal communication and negotiation with readers/listeners.

Scholars have classified metadiscourse in different ways. Classification by Crismore, Markkanen and Steffensen [4] is adopted in this study. They classified metadiscourse into two main categories, textual metadiscourse and interpersonal metadiscourse. Textual metadiscourse is used to explicit discourse structure, interpersonal metadiscourse is used to establish the relationship between the author and the reader by reader dialogue. The specific metadiscourse classifications are shown in Figure 1.

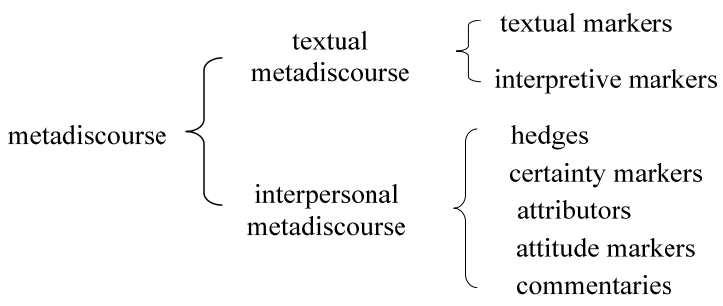

FIGURE I. METADISCOURSE CLASSIFICATION 
According to Cheng Xiaoguang and Jiang Hui [5] textual markers are used to show the cohesion and coherence relationship between paragraphs and between sentences. They include logical conjunctions (and, but, in addition to, however), ordinal numerals (first, second, next, in the third place), clue words (as we noted earlier) and topicalizers (there is, there are, as for, in regard to) and so on.

Interpretive markers are used to explain or define terms and new words in texts or explain author's illocutionary act. They include code glosses (namely, in other words, for example), illocution markers (to summarize, we claim that, to sum up), narrators (I announce that, according to James) and so on.

Hedges indicate the writers/speakers' speculation and doubt to the opinions that they are going to express (may, might, maybe, perhaps, possible).

Certainty markers indicate the certainty and confidence to something (certainly, It is true that).

Attributors indicate information sources and indicate indirectly the writers/ speakers' view on something, which show the objectivity (according to $\mathrm{X}, \mathrm{X}$ says).

Attitude markers indicate the writers/speakers' attitude to something, wish or surprise for example (I hope, I find it surprising that).

Commentaries directly express to the readers/listeners evaluations on a particular point of view (you may not agree, the reason for these choices are simple, most of you will oppose the idea that...).

Since the late 1950s when the term metadiscourse was proposed, scholars from China and abroad have done a lot of discussions and researches on metadiscourse. Some of them are theoretical studies in which the definition, character and classification of metadiscourse was discussed (Crismore 1989, Hyland 2005, Cheng Xiaoguang and Jiang Hui 2008). Some are applied researches combined metadiscourse with different aspects of language teaching, such as reading (Meyer et al. 1980, Crismore 1984, Vande Kopple 1985, Crismore and Vande Kopple 1988), writing (Cao Fenglong and Wang Xiaohong 2009) and oral English (Li Shucang and Sun Yifeng 2008, Kong Rui and Xin Xin 2009). However, there have not been any researches on metadiscourse combined with interpretation teaching in China yet. This empirical study will apply the relative theories of metadiscourse with college English interpretation teaching.

\section{RESEARCH DESIGN}

In order to clarify the relationship between metadiscourse and college English interpretation teaching, we will research on the following two questions. First, whether metadiscourse training has a significant impact on students' interpretation achievement? Second, if so, how does metadiscourse training influence students' interpretation achievement?

\section{A. Participants}

This research was carried out in two junior classes of English programs in a foreign languages university in China. One class was selected as the experimental group by random sampling. There are 28 students in this group (6 males and 22 females). The other class was taken as the control group. There are also 28 students in this group (6 males and 22 females). This experiment lasted for one semester (16 weeks).

\section{B. Procedures}

In the first week of the semester, students of both experimental group and control group were asked to finish an interpretation test, which was taken as pre-test. The relevant data were collected. From the second week, students of the experimental group were given an extra three-stage metadiscourse trainings in their interpretation classes. In the first stage, the lecturer guided students of experimental group to read two theoretical papers on metadiscourse, which are Some Exploratory Discourse on Metadiscourse by Vande Kopple and Theories and Applications of Metadiscourse by Cheng Xiaoguang. By reading these two papers, students could understand the basic concept and classifications of metadiscourse. In the second stage, based on students' understanding of the basic concept and classification of metadiscourse, the lecturer listed some sample words and sentences and asked the students of experimental group to classify them. In this way, students could have a better understanding of metadiscourse. In the training of this stage, there was also a discussion in which students discussed how metadiscourse training would promote their interpretation achievement. In the third stage, students of experimental group have mastered the basic concept, classification and usage of metadiscourse. Combined with the discussion results in the second stage, the lecturer gave interpretation lectures combined with metadisourse training in the three stages of interpretation which are input, transcode and output. Students of control group had the same interpretation lectures but without any specific training on metadiscourse.

Finally, after the experiment for the whole semester, students of both groups were tested again with another interpretation test paper in the last week of the semester. Data were collected for the analysis of the effect of metadiscourse training. In addition, after the training, 6 students of the experimental group were randomly selected for interview.

\section{Data Collection}

Both the pre-test and post-test in this study adopted the form of record interpretation test. They were carried out in the language laboratory of the university. The evaluation criteria are information accuracy and completeness, fluency, pronunciation and intonation. Students' interpretation scores were assigned based on evaluation criteria by three experienced teachers of interpretation courses of English program respectively according to their test records. The scores data by three teachers were analyzed to test the reliability with Statistical Product and Service Solutions. The statistical result showed that there is a strong correlation among the scores by the three teachers. The Alpha coefficient is 0.893. This indicated that the scoring results are with high reliability. Subsequently, the final scores of every test recorded were the average scores by the three teachers. In addition, the student interview was recorded and then transcribed for later analysis. 


\section{RESULTS}

The average scores by three teachers were input to the computer. The pre-test scores, post-test scores of both groups and the change of scores of experimental group and control group before and after the experiment were statistically analyzed with SPSS 11.5. The statistical results of students' scores of both groups were shown in TABLE 1.

TABLE I. THE STATISTICAL RESULTS OF STUDENTS’ PRE-TEST SCORES

\begin{tabular}{cccccc}
\hline groups & $\begin{array}{c}\text { student } \\
\text { number }\end{array}$ & mean & SD & T value & $\begin{array}{c}\text { significant } \\
\text { level }\end{array}$ \\
\hline $\begin{array}{c}\text { control group } \\
\text { experimental } \\
\text { group }\end{array}$ & 28 & 83.392 & 4.909 & & \\
\hline
\end{tabular}

Note: $* \mathrm{P}<0.05 ; * * \mathrm{P}<0.01 ; * * * \mathrm{P}<0.001$

Table 1 shows that before the metadiscourse training, the average score of control group is 83.392. This is slightly higher than the average score of experimental group (82.750). By hypothesis test, we found that there is no significant difference between the average scores of these two groups. Therefore, it can be approximately taken that the average scores of these two groups were more or less the same before metadiscourse training. The post-test results after the experiment were shown in TABLE 2.

TABLE II. THE STATISTICAL RESULTS OF STUDENTS’ POST-TEST SCORES

\begin{tabular}{cccccc}
\hline groups & $\begin{array}{c}\text { student } \\
\text { number }\end{array}$ & mean & SD & $\begin{array}{c}\text { T } \\
\text { value }\end{array}$ & $\begin{array}{c}\text { significant } \\
\text { level }\end{array}$ \\
\hline $\begin{array}{c}\text { control group } \\
\text { experimental } \\
\text { group }\end{array}$ & 28 & 84.107 & 4.323 & & \\
\hline & 28 & 85.928 & 4.323 & 1.749 & $0.046^{*}$ \\
\hline
\end{tabular}

Note:* $\mathrm{P}<0.05 ; * * \mathrm{P}<0.01 ; * * * \mathrm{P}<0.001$

Table 2 shows that after the metadiscourse training, the mean value of experimental group (85.928) is higher than that of the control group (84.107). By hypothesis test, we found that there is a significant difference between the scores of experimental group and control group. It means that after the metadiscourse training for the whole semester, the scores of the two groups are not equivalent any more, they are in a different level. Then we did a statistical analysis on the achievement change in pre-test and post-test of the control group and the experimental group. The results are shown in TABLE 3.

TABLE III. THE ACHIEVEMENT CHANGE BEFORE AND AFTER THE EXPERIMENT

\begin{tabular}{ccccccc}
\hline groups & student & $\begin{array}{c}\text { mean } \\
\text { number }\end{array}$ & SD & $\begin{array}{c}\text { T } \\
\text { value }\end{array}$ & $\begin{array}{c}\text { significant } \\
\text { level }\end{array}$ \\
\hline \multirow{2}{*}{$\begin{array}{c}\text { pre- } \\
\text { group }\end{array}$} & $\begin{array}{r}\text { test } \\
\text { post- } \\
\text { test }\end{array}$ & 28 & 83.392 & 4.909 & -0.605 & 0.275 \\
& $\begin{array}{r}\text { pre- } \\
\text { test }\end{array}$ & 28 & 82.750 & 4.359 & -3.048 & $0.0025^{* *}$ \\
experimental \\
group & $\begin{array}{r}\text { post- } \\
\text { test }\end{array}$ & 28 & 85.928 & 4.642 & & \\
\hline
\end{tabular}

Note: $* \mathrm{P}<0.05 ; * * \mathrm{P}<0.01 ; * * * \mathrm{P}<0.001$

Table 3 shows the comparison result of the pre-test and post-test scores of two groups. By comparing the pre-test and post-test scores of the control group, it can be seen that its mean value of post-test is higher than its mean value of pre-test, but there is no significant difference between them. By comparing the pre-test and post-test scores of the experimental group, we found that there is a significant difference $(\mathrm{P}<0.01)$ between its pre-test score and post-test score. The mean value of its post-test score is significantly higher than that of its pretest score. The above results show that by the metadiscourse training for the whole semester, the achievement of the experimental group is significantly higher than that of the control group. Therefore, it can be said that metadiscourse training has a significant effect on the improvement of students' interpretation achievement.

\section{DISCUSSION}

The above results show that metadiscourse training helps to improve students' interpretation achievement. Combined with metadiscourse training and students interview at the end of the semester, we think that metadiscourse training may help to improve students' interpretation achievement in the following three aspects.

Firstly, metadiscourse learning helps to understand and predict the logical relationship of different meaning levels of the source language, so as to promote students' understanding of interpretation input. According to Liu Boxiang [6], interpretation is a fundamental mode of input-transcode-output, which is carried out closely around the meaning of source language. The process of interpretation is composed of three closely connected procedures. In the first procedure, you have to hear clearly the source language, analyze and understand the meaning of the source language and the logical relationship of different meaning levels. In this procedure, interpreters should always try to guess and figure out the speakers' ideas, discourse directions and make reasonable judgments. Metadiscourse learning helps students predict and understand the logical relationship of different meaning levels of the source language more quickly and more accurately, so as to achieve the purpose of better understanding of the source language. Therefore, metadiscourse leaning is especially helpful to Chinese students' understanding of English language in English to Chinese interpretation. This is also proved in the student interview. One student mentioned, "Before I learn metadiscourse, I have not paid much attention to logical conjunctions, narrators and other kinds of metadiscouse in interpretation. After the systematical learning of metadiscourse under the guidance of our lecturer, I started to pay more attention to these words. And it seems that I can understand more than before."

Secondly, metadiscourse learning helps with note-taking and brain memory in interpretation. According to Huang Jianfeng [7], the famous Chinese translator Ji Chaotao has once described the relationship between logic and memory, "Nobody can grab hundreds of pearls scattered in the disk with only both hands. However, if we string the pearls together, we can pick them up with only one finger". One of the main contents of note-taking in interpretation are conjunctions which illustrate the causes and effects of different contents and suggest the logical relationship. Therefore, metadiscourse which embodies the discourse logical relationship and the speakers' attitude can act the role of “string” to improve interpreters' memory.

Thirdly, metadiscourse learning helps Chinese students with their English expression when they do Chinese to English 
interpretation. The second procedure of interpretation is to form the source language meaning in the target language and to express the source language meaning in the target language as soon as possible. As we all know that Chinese language emphasizes on "parataxis", whereas English language emphasizes on "hypotaxis". To some extent, this difference between Chinese and English causes the unskilled use of English conjunctions by Chinese learners of English. The metadiscourse training in interpretation teaching makes students pay more attention to their English output in Chinese to English interpretation. In this way, they not only try to express the meaning of source language and convey the information, but also pay special attention to the structure and cohesion of the target language. For example, the master of textual markers which are used to show the cohesion and coherence relationship between paragraphs and between sentences helps with the expression in target language.

This study confirmed that metadiscourse training in interpretation teaching helps with the improvement of students' interpretation achievement. Therefore, teachers can do the relevant metadiscourse training in interpretation teaching to improve students' interpretation achievement. This study also discussed how metadiscourse training helps with the improvement of interpretation achievement. The opinions listed are based on this experiment and the authors' daily interpretation teaching. They need further discussion and verification. How metadiscourse training helps with the improvement of students' interpretation achievement in other aspects also needs further studies.

\section{ACKNOWLEDGEMENTS}

This paper is supported by Innovation Program of Shanghai Municipal Education Commission.

\section{REFERENCES}

[1] Mei Deming. An Advanced Course of Interpretation [M].Shanghai: Shanghai Foreign Language Education Press, 2000.

[2] Jiang Hui, Cheng Xiaoguang. Overview of the Study of Metadiscourse [J].Journal of Northeast Normal University (Philosophy and Social Science), 2009(1).

[3] Crismore A. Talking with Readers: Metadiscourse as Rhetorical Act [M] New York: Peter Lang Publishers, 1989.

[4] Crismore A, Markkanen R and Steffensen M S. Metadiscourse in Persuasive Writing [J]. Written Communication, 1993(10).

[5] Cheng Xiaoguang and Jiang Hui. Metadiscourse, its translation in Chinese [J]. Foreign Languages and Their Teaching, 2008(5).

[6] Liu Boxiang. Observations and Reflections on Interpretation Courses [J]. Foreign Languages and Their Teaching, 1998(6).

[7] Huang Jianfeng. Discussion on the Advanced Interpretation Training from British Interpretation MA Program [J]. Foreign Language World, 2005(3). 